\title{
An Emqirical Study on Teaching Listening in CLT
}

\author{
Tsinghong Ma \\ School of Foreign Languages \\ Shandong Econonic University \\ Jinan250014, China
}

\begin{abstract}
In the traditional ELT in China, much emphasis has been put on the students' mastering vocabulary and grammar. Language form was regarded as the content of teaching. And listening skill has been ever neglected for a fairly long time in ELT in China. Recent years, more and more attention has been drawn to learners' listening ability. This paper introduces teaching listening course at college level in communicative approach, which involves background knowledge introduction and into which various skills: speaking, reading and writing are integrated. It discusses the task design, strategy training, possible teaching plan, classroom arrangement; and presents an empirical study in this approach.
\end{abstract}

Keywords: Communicative language teaching, Listening comprehension, Skills integration, Background knowledge

\section{Introduction}

In modern times, the world has shrunk and in many cases interpersonal communication is now more vital than academic usage. It is now important for the learner to be equipped with the command of English which allows him to express himself in speech or in writing in a much greater variety of contexts. Learning to use a language thus involves a great deal more than acquiring some grammar rules and vocabularies and a reasonable pronunciation. It involves the competence to suit the language to the situation, the participants and the basic purpose. Conversely, and equally important, it involves the competence to interpret other speakers to the full.

It is observed that language students are best motivated by practice in which they sense that language is truly communicative. The teacher's skills are moving them forward to a fuller competence. In the traditional ELT in China, much emphasis has been put on the students' mastering vocabulary and grammar. Language form was regarded as the content of teaching. There are signs that linguists are turning language teachers' attention to the communicative properties of language and the functioning of language in social context. Influenced by these functional and social-cultural linguists, language teachers are paying more attention to the function of language.

Listening skill has been ever neglected for a fairly long time in ELT in China. This led to that graduates who have been studying English for about 10 years don't have a satisfying proficiency on listening comprehension and speaking. Actually a person's speaking proficiency is directly related to his listening ability. However, this problem has been realized and measures have been taken to improve the situation. For example, many colleges and universities have opened "listening" or "listening and speaking" courses, listening textbooks are being developed, language lab has been improved and increased. Moreover, listening test has been added to CET and PETS. Listening as an important way of getting information is getting more and more attention.

\section{An Analysis of Current Listening Teaching Situation}

Although more and more colleges are opening listening course for undergraduates of non-English major, the situation is far from satisfying. The main complaints are: the text is too hard; there is no interest in this course (boring); it's easy to get tired and sleepy; the improvement is not obvious, etc.

A questionnaire was ever carried by the author during her students, and the only one question is "what are your problems in listening to English?" According to their answers, the problems concentrate on the following items:

1) Trouble with sounds: I have trouble catching the actual sounds of the foreign language.

2) Have to understand every word: I have to understand every word; if I miss something, I feel I'm failing and get worried and stressed.

3) Can't understand fast, natural native speech: I can understand people if they talk slowly and clearly; I can't understand fast, natural native-sounding speech.

4) Need to hear things more than once: I need to hear things more than once in order to understand. 
5) Find it difficult to keep up: I find it difficult to "keep up" with all the information I am getting and can't think ahead or predict.

6) Get fired: If the listening goes on a long time I get tired, and find it more and more difficult to concentrate.

7) Insufficient vocabulary: My vocabulary is smaller than the text demands and there are some words that I can't understand.

These problems are typical among college students in their listening to foreign languages. When we analyze these items, we can see some of them are concerning the "bottom-up process" (e.g. Item 1, 3, and 7) The core difficulty for them lies in discriminating sounds in connected speech: strong and weak forms and modification of sounds, including assimilation, elision and liaison etc.

Some of the items are concerning the "top-down process"(e.g. Item 5). They show that there is a lack of background knowledge in listening comprehension. Item 2 and 5 show that the students need listening strategy-training (selective listening and prediction).

The reasons that bring these problems are various. They relate to teaching material (too difficult for most cases), teaching plan (too much content in limited time), teaching purpose (teaching for passing exams), students' motivation (attention paid to listening is not enough), so on and so forth. Among them the most important cause, in fact, should be teaching methods.

The general teaching mode in listening classroom at colleges is quite simple and widely used: the teacher play the recorder and the students do exercises after listening. No background knowledge introduction, no strategy training, no discussion and negotiation, no speaking, reading and writing - skills integration, the tasks and exercises are boring, no encouragement for response... Actually testing is far more than training during this class. It is hard to see that the students are being taught any particular skill in such a class. What weaker students inevitably and rapidly learn is that they are weak in listening comprehension in the foreign language. Naturally the students are becoming less and less motivated. And these directly lead to the students' poor communicative competence on listening comprehension.

In order to solve the problems and improve the situation, a variety of measures can be taken. Besides strengthening the students' linguistic competence (pronunciation, vocabulary, grammar, discourse,etc.), we have other means to help them improve their communicative listening competence.

\section{Measures to Improve Communicative Listening Ability}

\subsection{Teaching Stages}

Harmer (1991) suggests a basic methodological model for the teaching of receptive skills, which in the author's opinion is to a large extent acceptable:

The model has five basic stages which are:

\section{1) Lead-in}

Here the students and the teacher prepare themselves for the task and familiarize themselves with the topic of the listening tasks and exercises. One of the major reasons for this is to create expectations and arouse the students' interest in the subject matter of the spoken or written text.

2) Teacher directs comprehension task:

Here the teacher makes sure that the students know what they are going to do. Are they going to answer question, fill in a chart, complete a message pad or try and re-tell what they heard/saw? This is where the teacher explains and directs the students' purpose for listening.

3) Students listen for task

The students then read or listen to a text to perform the task the teacher has set.

4) Teacher directs feedback

When the students have performed the task the teacher will help students to see if they have completed the task successfully and will find out how well they have done. This may follow a stage in which students check their answers with each other first.

5) Teacher directs text-related task

Teacher will then probably organize some kind of follow-up task related to the text. Thus if the students have filled a form based on a heard discussion, the text-related task might be to discuss in groups the same or related topic.

\subsection{Background Knowledge Introduction}

According to schema theory, listeners might need to use their background knowledge to work out what various 
reference items might refer to. Here we are dealing with the prepositional level of language. Let us now look at how background knowledge might help us interpret discourse on a functional level. When studying functions, the question is not "what is the speaker trying to tell us about events and things in the world?" but "what is the speaker trying to achieve through language?" Widdowson provides an interaction to demonstrate the points he wishes to make:
A: I have two tickets to the theater tonight.
B: My examination is tomorrow.
C: Pity.

What are our fictional speakers trying to do here? According to Widdowson, there are implicit assumptions on both sides that A's first statement is an invitation. B's response, which, on the surface, has little to do with A's statement, is taken as a refusal of the invitation. This is recognized in A's final remark. Of course, the encounter may not have gone quite as smoothly as this. Consider the following exchange, in which A's opening gambit is intended as an invitation. Shat do you think the speakers are trying to do in the other utterances in the exchange?
A: I have two tickets for the theater tonight.
B: Good for you. What are you going to see?

\section{A: Measure for Measure \\ B: Interesting play. Hope you enjoy it.}

The negotiation is not going to plan, and A has to renegotiate to return to his original discourse strategy.

\section{A: Look, are you free tonight? \\ B: I'm not sure, why?}

The message is still not getting across, so he tries again.

A: Well, I'd like to invite you to come to the theater with me.

\section{B: Well, actually my exam is tomorrow.}

Now Widdowson allows A to be obtuse.

\section{A: I know, so is mine. What's that got to do with it?}

These negotiating procedures depend crucially on the participants knowing what each utterance stands for functionally (that is as "invitation", "polite refusal", etc.) The implication on ELT is, the student must have enough background knowledge of the culture, knowledge which is relevant to the particular instance of the language he is concerned with, to enable him to assess why what is being said is being said. We would assume that the more the background knowledge which is assumed in a particular discourse, the more difficult that discourse will be for the student to understand if he does not share that knowledge. Therefore, background knowledge is an important part of listening teaching.

\subsection{Important Listening Strategies Training}

From the former chapter we have seen learning strategy training is beneficial to foreign language or second language learning. For listening comprehension, there are a variety of strategies. According to Nunan (1999), the following are some of the most important strategies with examples:

1) Listening for gist:

e.g. Is the speaker describing a vacation or a day in the office? Is the radio report about news or weather?

2) Listening for purpose:

e.g. Are the speakers making a reservation or ordering food? Is the speaker agreeing or disagreeing with the suggestion?

3) Listening for main idea:

e.g. Why is the speaker asking the man questions? Did the speaker like or dislike the movie?

4) Listening for inference:

e.g. What are the speakers implying by what they said?

1)Listening for specific information:

e.g. How much did they say the tickets cost? Where did she say the meeting was being held?

2) Listening for phonemic distinctions:

e.g. Did the speaker say first or fourth? Did the speakers say they can or can't come to the party? 
3) Listening for tone/pitch to identify speaker's attitude:

e.g. Did the speaker enjoy the wedding or not? Is the speaker surprised or not?

4) Listening for stress:

e.g. What is more important, where he bought the watch or when?

In the process of listening class, the teacher should integrate these strategies into listening tasks and get them introduced to the students naturally.

\subsection{Skills-integrated task design}

In designing listening tasks, now we can naturally conclude that teachers couldn't take listening as the sole skill and goal. Since in real life, skills are actually combined for people to communicate; and in language learning the learner can directly see the value of one skill in the general language development when it is integrated into the others. This is also a good way for students to give proper responses to what they have heard.

So teachers should bear in their mind the principle of skills-integration when designing and carrying on a listening task. That is, in completing a listening task, the other three skills--speaking, reading and writing can possibly involved.

The following case as an example to communicative listening teaching can illustrate the above ideas.

\section{A Lesson Plan of Listening Teaching}

This is a case based on the theory of CLT, which is carries out in the English reading course to the students at college level.

\subsection{Text}

The teaching material is Listen To This: 1, Lesson Ten, Section Two.

Tapescript

A. Discussion

Eddie is talking to Tom.

Eddie: Have you ever been really frightened?

Tom: I suppose so, once or twice.

Eddie: Can you remember when you were most frightened?

Tom: That isn't difficult.

Eddie: What happened?

Tom: Well, we used to have a favorite picnic place beside a lake. We had a boat there. I was there with some friends and I decided to swim to a little island. It didn't look far and I started swimming ... but half way across I realized it was a lot further than I thought. I was getting very tired. I shouted. Luckily my friends heard me and brought the boat. I thought I was going to drown. I've never been more frightened in my life.

B. Forum:

Should school children take part-time jobs?

This is a discussion which will appear in a magazine.

Editor: This month our panel looks at part-time jobs. Are they good for school children or not?

Headmaster: Definitely not. The children have got two full-time jobs already: growing up and going to school. Part-time jobs make them so tired they fall asleep in class.

Mrs. Barnes: I agree. I know school hours are short, but there's homework as well, and children need a lot of sleep.

Mr. Barnes: Young children perhaps, but some boys stay at school until they're eighteen or nineteen. A part-time job can't harm them. In fact, it's good for them. They earn their pocket-money instead of asking their parents for it. And they see something of the world outside school.

Businessman: You're absolute right. Boys learn a lot from a part-time job. And we mustn't forget that some families need the extra money. If the pupils didn't forget that some families need the extra money. If the pupils didn't take part-time jobs they couldn't stay at school.

Editor: Well, we seem to be equally divided: two for, and two against. What do our readers think?

\subsection{Teaching goal}

Title: Should School Children Take Part-time Jobs 
Function: Describing a series of actions

Stating views and the arguments

Notion: agree, be for..., be against...

\subsection{Teaching Procedure}

Lead-in

1) Questions: Do you have experience of being really frightened?

Can you describe it to us?

Do you have a part-time job? Why do you take it? How do you like the experience?

Method: discussion in the whole class

2) Vocabulary Study: panel, full-time, absolutely, extra, picnic, drown

Teacher directs comprehension task

"In this section we'll listen to a description on an experience of being frightened first and then the second part will be a forum on whether taking part-time job is good for children or not."

Students listen for task

A. Discussion

1. Listen to the tape once and then try to work out a summary for this conversation.

Summary: Tom is telling Eddie about

( strategy: general listening )

2. Fill in the missing words.

We used to decided to place beside We had . I was there with and I thought. I was more It didn't look far and I __ ...but I realized it was than I in my life. and brought I thought I I've never been

(strategy: listening for specific information)

B. Forum

3. Complete the remarks given by the four participants at the forum so as to show each one's answer to the question: Should school children take part-time jobs?

Headmaster:

(1) The two full-time jobs that children have already got are:

a. , and

b.

(1) Part-time jobs make them that they in class.

Mrs. Barnes:

(2) What children need is

Mr. Barnes:

(3) A part-time job can't boys.

(4) They instead of asking their parents for And they of the world

Businessman:

(1) Boys from a part-time job.

(2) If the pupils they couldn't

(strategy: listening for gist)

Teacher directs feedback

After the students finish the tasks, they check their answers with each other first. Then the teacher talked about the answers with them. 


\section{Teacher directs text-related task}

1) Write a short passage describing as vividly as you can an experience of being extremely happy.

2) The task is to discuss in a small group "Do you agree that taking part-time job is good for school children? Why or why not?" Then each group will recommend a representative to present the (may be) different views of the members in his group and his own opinion on this issue with the argument.

\subsection{Conclusion}

The whole procedure of teaching listening section is designed according to the functional/notional and task-based syllabus. At each stage of reading, a definite task is proposed and the class is student-centered. Pair and group work, as language learning activities, is a useful technique for guiding the language learners towards better and easier communication. This type of practice gives the whole class maximum opportunities for practicing the language. The students are encouraged to discuss in groups and state individually. Some listening strategies which greatly help their listening are presented. Speaking and writing are integrated into the tasks. The students keep interest in the target text all the time. The atmosphere in the classroom is active and pleasant.

Through the tasks, the students get a deep impression of how to express their views and communicate with each other. They have desired the language function.

\section{A Case Study on Effect of Teaching Listening In CLT}

\subsection{Objectives}

The recent developments in language teaching have been motivated by a number of factors, such as changes in linguistics, in learning psychology, and in the social environment, with the increasing importance of global institutions. Also, increasing dissatisfaction with the results of earlier methods leads to a search for more efficient methods and approaches.

As we mentioned in the former part, listening as an important means of input has been neglected for a long time. It seems a hut nut for most students; while the present teaching of listening comprehension is generally unefficient. The main reason, as we have analysed, lies in the teaching methods. The traditional method is simple, dull, unscientific, discouraging and more seriously, it can not help the students improve their communicative competence.

Starting from the current needs of foreign language learning, we have found some of Communicative Language Teaching principles can be borrowed to apply to English teaching classroom. On listening teaching it is also of value. In Chapter 4, we have discussed the possible ways to realize the ideas of making listening training more efficient in CLT. The specific suggested ways are vivid Background knowledge introduction, Strategy training, and skills-integration Tasks, which, for the sake of convenience, will be referred to as "BST" in the following part.

The experiment to be introduced here is a preliminary study of listening comprehension at college level in the light of CLT, which advocates the importance of communicative competence. This study intends to Investigate how the instruction affects the listening comprehension performance, and how language proficiency relates to the results. Thus, two research questions are formulated:

1) Does BST affect the listening performance of the students?

2) Does BST help the students improve communicative competence as demonstrated by an increase in reading comprehension?

\subsection{Research Design}

\subsubsection{Sample}

The general principles of sampling in this study are: 1) taking intact classes as subjects; 2) the subjects being typical and representative. The particiants in this study were two classes, 89 first-year non-English majors of Shandong Institute of Commerce and Technology. The two classes are from the oldest and largest department-Engineering and Technology Department, whose students' English Proficiency has generally been in the middle of all departments. The selection of the two classes also intended to control as many variables as possible. The subjects were of very similar academic and family background. They were all engineering students and most of them from rural areas.

A background questionnaire was designed to determine how similar the two classes were in the following areas: previous listening experience, types of high school, sex proportion, grades in the placement test, family background. Analysis of mean difference of the data obtained between the two groups using Chi-square test and t-test found that the two groups did not differ significantly on any of the background characteristics (Table 1). Then one of the two classes was randomly appointed as an experimental group and the other as a control group.

Insert Table 1 Here 


\subsubsection{Treatment}

The experiment consisted of an 18-week BST instruction program. Both of the control and experimental groups took part in the regular first semester /English listening course. They met twice a week in 50-minute classes, used the same course materials (Listen To This: 1 edited by Beijing University For Foreign Studies), and followed the same syllabus, the only difference being that the experimental group students were given BST instruction. Both the experimental and the control group were taught by the author. Different lesson plans for the experimental group focused on introducing necessary background knowledge, listening strategy training and completing various tasks

\subsubsection{Instrumentaion}

\section{Measures of Teaching Listening in CLT}

\section{1) Background knowledge Introduction}

In order to help the students understand the listening material by Top-down processing, necessary such kind of knowledge was introduced in various and attracting forms: teacher's presentation, pictures-showing, video-showing, discussion, etc.

\section{2) Listening Strategy Training}

The strategies training was integrated into the regular coursework rather than as a separate component and usually underlined in listening tasks.

\section{3) Skills-integration Tasks}

One of the outstanding features of CLT is task-based classroom activities. In the listening classroom for experiment group, besides the tasks in the course book, the author designed other text-related tasks for most of lessons. In these tasks, not only listening skill but also speaking, reading and writing skills are involved.

\section{Time Arrangement}

Since the two groups have the same syllabus and class time is also equal, while in the class of experimental group there are more interactive activities, time should be controlled properly. The treatment is: usually in class for control group, the last 10-15 minutes would be used to re-listen all of the content that the students had heard during that class. For experimental group this period of time was employed to carry on BST measures.

\section{Measures of Listening Comprehension Performance}

Two parallel tests were designed especially for the study to measure the subjects' listening comprehension performance. Four teachers sere invited in the designing job. Each presented one type of listening tasks for four samples. One sample included: 1) multiple-choice for understanding short conversations; 2) multiple-choice for understanding short passages; 3) compound dictation; 4) answering questions. These types of tasks are corresponding to those suggested for the National College English Test (Band IV). Then the experimenters organized the sample test papers into the final ones.

To guarantee reliability and a moderate difficulty, and to see if the two tests are parallel ones, a pretest was first administrated to 30 randomly selected first year students (none of the students involved in this present study was included). For the test lasting less than half an hour, the students were asked to finish the two tests at one time with only an interval of twenty minutes. Table 2 shows that the two tests can be used as parallel tests.

\section{Insert Table 2 Here}

\subsection{Data Collection and Analysis}

After the students had experienced the listening course for one week, both the experimental and control group were given a pre-test to measure the listening comprehension performance and the questionnaires to elicit what they actually did in listening activities. At the end of the semester, a posttest and the questionnaires were administrated again to determine students' improvement in listening performance and the change of strategies use. The data thus obtained were analyzed by means of SPSS. The analysis procedures involved are as follows: To determine the studentl' improvement in listening comprehension performance, the pre- and post-test mean scores were first compared using one-way ANOVA between the experimental and the control group. Then the significant difference in the gain scores ( post-test score minus pre-test score) between the two groups was tested by paired sample t-tests separately within the treatment and control group.

\subsection{Statistical Results}

The results of the statistics generated by One-way ANOVA analysis in Table 3 show that there is no difference in pretest between the experimental group and the control group $(\mathrm{P}=.924)$, whereas a significant difference is seen in the posttest $(\mathrm{P}=.001)$, indicating that the treatment to the students seems to have caused some change. 
The result was further tested by the paired sample t-test. Compared with the pretest, the experimental group made a significant progress (P .000 .05) in the posttest, while the control group found no clear improvement Table 4). Thus, a couclusion may be drawn here that the explicit strategy training is successful for improving listening proficiency. In addition, the P-value obtained from the ANOVA analysis for the posttest is .001, indicating that this is a very strong effect.

Insert Table 4 Here

\subsection{Discussion of the Statistical Results}

From the data collected and the subsequent statistical analysis of the data, it would seem that adding BST training component to listening course has a significant effect in the areas investigated in this study. It appears to have greatly improved the experimental subjects' listening comprehension performance.

Compared with the control class, the experimental class achieved significant improvement in listening performance. The result is consistent with the objectives of the treatment since emphasis was placed on effective BST for improving listening performance.

Generally, unlike the traditional listening classes attended by the control group in this study in which the teacher only used listening activities to test the listening abilities of the students, emphasizing outcome and leading to anxiety and apprehension, BST teaching focused on the process by exposing students to a rich background knowledge and various effective and efficient listening strategies for approaching listening tasks of different types, opening up less frustrating routes to successful listening. These activities might become more relevant and interesting for the learners. Being actively involved and strategically smart, the students are more likely to make greater progress.

It is obvious that this study is not a strictly complete one. With regard to what roles each part of BST plays on the students respectively, no answer is supplied. To achieve this goal, more experiments need to be put up.

\section{References}

Brown G. (1990). Listening to Spoken English (second edition). New York: Longman Group UK Limited.

Dornyei, Z. (1995). “On the teachability of communicative strategies”. TESOL Quarterly, 29-1.

Harmer, J. (2000). How to Teach English. Beijing: Foreign Language Teaching and Research Press.

Johnson, K.E. (1995).Understanding Communication in Second Language Classrooms. Cambridge: Cambridge University Press.

Larsen-Freeman, D. (2000).Techniques and Principles in Language Teaching. Oxford: Oxford University Press.

Nuan, D. (1989). Designing Tasks for the Communicative Classroom. Cambridge: Cambridge University Press.

Nuan, D. (1999). Second Language Teaching and Learning. Heinle \& Heinle.

Oxford, R. (1990). Language Learning Strategies: What Every Teacher Should Know. Boston: Newbury House.

Rost, M. \& Ross, S. (1991). "Learner use of strategies in interaction: typology and teachability". Foreign Language journals, 29-3.

Rost, M. (1990). Listening in Language Learning. New York: Longman.

Savignon, S.J. (2002). Interpreting Communicative Language Teaching. New Haven \& London: Yale University Press.

Widdowson, H.G. (1990). Aspects of Language Teaching. Oxford: Oxford University Press.

$\mathrm{Xu}$, Tsiang. (2000). Communicative English Language Teaching and Testing. Shanghai Foreign Language Education Press. 
Table 1. Background Characteristics of the Sample

\begin{tabular}{|c|c|c|c|c|}
\hline & & C Group & E Group & Test \\
\hline \multirow{3}{*}{ Sex } & Female & 8 & 9 & \multirow{3}{*}{$\begin{array}{l}X^{2}=.153 \\
D f=1 \\
P=.695\end{array}$} \\
\hline & Male & 37 & 35 & \\
\hline & Total & 45 & 44 & \\
\hline \multirow{3}{*}{ High school } & Key & 18 & 21 & \multirow{3}{*}{$\begin{array}{l}\mathrm{X}^{2}=.939 \\
\mathrm{Df}=1 \\
\mathrm{P}=.331\end{array}$} \\
\hline & Ordinary & 27 & 23 & \\
\hline & Total & 45 & 44 & \\
\hline \multirow{3}{*}{$\begin{array}{l}\text { Previous } \\
\text { listening }\end{array}$} & Yes & 11 & 12 & \multirow{3}{*}{$\begin{array}{l}X^{2}=.908 \\
D f=1 \\
P=.757\end{array}$} \\
\hline & No & 34 & 32 & \\
\hline & Total & 45 & 44 & \\
\hline \multirow{3}{*}{ Family source } & Urban & 14 & 15 & \multirow{3}{*}{$\begin{array}{l}X^{2}=.288 \\
D f=1 \\
P=.592\end{array}$} \\
\hline & Rural & 31 & 29 & \\
\hline & Total & 45 & 44 & \\
\hline \multicolumn{2}{|l|}{ Placement test } & 69.8 & 70.6 & $\mathrm{P}=.717>.05$ \\
\hline
\end{tabular}

Table 2. Statistical Results of the Two Tests

\begin{tabular}{|l|l|l|l|l|}
\hline & Mean & SD & P-value & R \\
\hline Test 1 & 18.80 & 5.04 & .53 & \multirow{2}{*}{.903} \\
\cline { 1 - 3 } Test 2 & 18.60 & 4.67 & .52 & \\
\hline
\end{tabular}

Note: P-value: index of difficulty

Table 3. One-way ANOVA of Pre- and Post-test of Listening Comprehension across Experimental and Control Group

\begin{tabular}{|c|c|c|c|c|c|c|}
\hline & Source & $\mathrm{SS}$ & df & MS & $\mathrm{F}$ & Sig. \\
\hline \multirow{3}{*}{ Pre-Test } & Between Groups & .22 & 1 & .22 & \multirow[t]{3}{*}{.009} & \multirow[t]{3}{*}{.924} \\
\hline & Within Groups & 1997.83 & 83 & \multirow[t]{2}{*}{24.08} & & \\
\hline & Total & 1998.05 & 84 & & & \\
\hline \multirow{3}{*}{ Post-Test } & Between Group & 258.80 & 1 & 258.80 & \multirow[t]{3}{*}{10.95} & \multirow[t]{3}{*}{.001} \\
\hline & Within Group & 1961.25 & 83 & \multirow[t]{2}{*}{23.63} & & \\
\hline & Total & 2220.05 & 84 & & & \\
\hline
\end{tabular}

Table 4. Paired Sample t-test on Pre- and Post-test of Listening Comprehension in Experimental and Control Group

$\begin{array}{llccccc}\text { Group } & \text { Pretest } & \begin{array}{c}\text { Mean } \\ \text { Posttest }\end{array} & \text { Gain } & \text { df } & \text { T } & \text { P } \\ \text { E Group } & \begin{array}{l}15.26 \\ (4.96)\end{array} & \begin{array}{c}19.42 \\ (4.96)\end{array} & +4.16 & 44 & 7.96 & .000 \\ \text { C Group } & \begin{array}{l}15.36 \\ (4.85)\end{array} & (4.75) & +.57 & 43 & 1.15 & 2.57\end{array}$

Note: E Group: experimental group; C Group: control group.

Below the means in parentheses are standard deviations. 